\title{
高尿酸血症に対する肥満の関与 一肥満はいつの時点からリスクとなりうるのであろうかー
}

太田原 顕 ${ }^{1}$ 久留 一郎 ${ }^{2}$

目的

近年注目されているメタボリックシンドロー ムの一疾患としての高尿酸血症に肥満の関与が どの程度㧍よぼすのか, どの時点から関与して いるのかを検討した。

\section{方 法}

当院人間ドックを受診し，20歳代の体重を問 うアンケートに有効回答した男性258例を対象と して, 現在体重, 収縮期血圧, 拡張期血圧, 血 清脂質, 空腹時血糖, $\mathrm{HbA} 1 \mathrm{c}$ などを測定した。 現在のBMIが25以上の肥満群 (OB) とそうでない 非肥満者群 (NOB) についてそれぞれの測定值に ついて検討した。

またメタボリックシンドロームの各項目に 1 点を与え算出した合計点数を20歳からの体重増 加を層別化した各群で (各 $10 \mathrm{Kg}$ 単位で) 比較検討 した。

\section{結 果}

OB群は76例，NOB群は182例であった。平均 年齢はどちらも49才であった。 BMIはそれぞれ $27.1 \pm 1.8$ vs $22.1 \pm 2.2$ とOB群で有意に高かった。 血清クレアチニン, 尿素窒素, 血糖, $\mathrm{HbA} 1 \mathrm{c} に$ は両群間で有意差は認められなかった。収縮期 血圧，拡張期血圧はそれぞれ128土16 vs $119 \pm$ $17 \mathrm{mmHg}, 82 \pm 11$ vs $77 \pm 12 \mathrm{mmHg}$ とOB群が有意 に高值を示した．総コレステロール值, 対数化 した中性脂肪值, HDLコレステロール值, LDL コレステロール值は208 \pm 34 vs $201 \pm 34 ， 2.12 \pm$
0.22 vs $1.97 \pm 0.21,52 \pm 15$ vs $61 \pm 17 \mathrm{mg} / \mathrm{dl}, \quad 138 \pm$ 31 vs $126 \pm 32 \mathrm{mg} / \mathrm{dl}$ とOB群で有意にいわゆる高 TG低HDLパターンを呈した. 血清尿酸值もOB群 で有意に高く $6.1 \pm 1.4$ vs $5.3 \pm 1.3 \mathrm{mg} / \mathrm{dl}$ であった。

20 歳代の体重はOB群で $64 \pm 10 \mathrm{Kg}$, NOB群で $56 \pm 7 \mathrm{Kg}$ で有意にOB群で高く，BMIはそれぞれ $22.6 \pm 2.4$ vs $20.5 \pm 1.8 \mathrm{Kg} / \mathrm{m}^{2}$ であった. また現在 体重までの増加体重割合はOB群で11.3土6.8であ るのに対しNOB群ではわずかに3.7 $\pm 7.0 \mathrm{Kg}$ であ った.メタボリックシンドロームの割合はOB群 で37.3\%NOB群で $4.33 \%$ と有意にOB群に多く認 められた。

20 歳代からの体重増加を $10 \mathrm{Kg}$ ごとに層別化し てみると $30 \mathrm{Kg}$ 以上体重の増えた群で有意にスコ アが上昇していた。

\section{考察}

高血圧や脂質代謝異常は肥満者に多いことは これまでも報告されてきたが, 肥満に至る群は 20歳代からすでに体重が多かった。しかしなが らその時点でのBMIは22程度であり決して肥満 であったわけではない。OB群はNOB群に比べて 体重増加が多い点を考えるとその後 (20歳以降) の食習慣を含む生活習慣の違いが両者の相違を 引き出した可能性が考えられる。このことは20 歳代でたとえBMIが正常であるにせよ食行動に 対する介入することが，将来の肥満群を減少さ せ，メタボリックシンドロームの割合を減らす うえで必要ではないかと思われた。
1 ) 山陰労災病院循環器科

2 ) 鳥取大学大学院医学系研究科機能再生医科学専攻再生医療学
Akira Ohtahara

Ichiro Hisatome 


\section{高尿酸血症・痛風の合併病態, Metabolic Syndromeから "Metabolic Domino"}

\section{目的}

高尿酸血症・痛風は心血管系危険因子の重積 病態を高い頻度で合併し，長期予後の観点から 重要な病態である。これら重積病態をmetabolic syndromeととらえ，生活習慣を含めた積極的な介 入の必要性が強調され,「高尿酸血症・痛風の治 療ガイドライン (2002)」のコアを形成している.

最近の本邦での若年化かつ増加傾向にある痛風 の多くは古典的痛風よりも, むしろmetabolic syndromeの病態としての痛風である，すなわち，生 活習慣の乱れ（運動不足, 動物性脂肪を中心とし たエネルギー過剩㩒取，アルコール消費量の増加 など), その結果内臓脂肪蓄積を最上流の病態と して，時間軸の流れのなかで高尿酸血症を含め, metabolic syndromeとしての各種危険因子の重積病 態を形成しながら, microangiopathy, macroangiopathyのさまざまな合併症を発症し，最終的に 心血管事故へとつながる。このような時間軸と の関係でmetabolic syndromeを捉えるものとし て, “metabolic domino” (伊藤 裕2003) の概念が 提唱されている。そこで, 痛風・高尿酸血症の 全人的管理にあたって，痛風を “metabolic domino”として据えることを提唱するために自験症 例により時間軸との関連で痛風患者の心血管系 危険因子の重積状態を検討した。

\section{対象と方法}

metabolic syndromeとして解析可能な自験痛風 症例（241例，男性）の各種臨床所見につき後乃

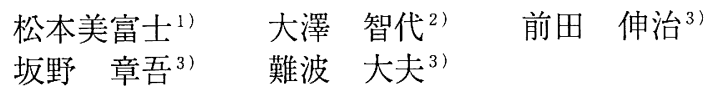

向き検討を行った。 metabolic syndromeの基準は NCEP-ATIIIのウエストサイズを日本人用に変更 し，本邦診断基準確定予定ものを用いた。観察 平均期間は5.7士3.9 (1.8-16.5) 年であった。イン スリン抵抗性はHOMA-Rを用いた。各種危険因 子のクラスタ分析，順序性を検討した。

\section{結 果}

自験例でmetabolic syndromeの基準に合致する ものは67.1\%であり，これら症例の心血管系危険 因子の出現順序は内臓脂肪蓄積 $\rightarrow$ イスリン抵抗 性 $\rightarrow$ 高血圧・高脂血症・食後高血糖 - 睡眠時無呼 吸症候群 $\rightarrow$ 糖尿病 - 動脈硬化性病変 $\rightarrow$ 心血管事故 であった。またこれら時系列とは無関係に危険 因子として, 高尿酸血症 $\rightarrow$ 痛風, 高Homocysteine 血症, 飲酒, 喫煙があり, これらの危険因子の時 系列での順序性は明らかでなかった。

\section{結 論}

痛風をmetabolic syndromeと捉えることの重要 性を，最終的な心血管事故の予防の観点から各 種危険因子の時系列的に捉え, 各時間軸にみあ った生活習慣の是正, 薬物療法の導入などが図 られる必要がある。したがって, 本邦で急速に 増加し, 若年化している痛風を内臓脂肪蓄積を 最上流に置き，“metabolic domino”の概念を導入 することが臨床的には重要である.
1 ) 山梨県立看護大学短期大学部看護科人間健康科学

2 ）愛知県豊川市民病院内科・リウマチ科

3 ) 名古屋市立大学大学院医学研究科臨床分子内科（膠原病内科）
Yoshifuji Matsumoto Tomoyo Ohsawa Shinji Maeda, Shogo Banno and Taio Naniwa 


\section{航空機乗員における高尿酸血症を中心とした 生活習慣病の経年的変化}

山口雄一郎 ${ }^{11}$

木村 弘章 ${ }^{11}$

市田 公美1)

目的

航空機乗員の航空身体検査 (AME) において, 無症候性高尿酸血症は不適合疾患ではないが，痛 風は突発性の操縦不能に至る危険性があることか ら不適合疾患となっている，従って航空機乗員に おけるこれらの病態を把握し，それに対応した予 防が航空機の安全運行につながる。また, 同一母 集団を長期間に渡り観察することにより，臨床的 により有益な情報を得ることが可能と考えた。今 回我々は航空医学研究センターにおけるAMEの デー夕を基に, 乗員全体における現状の把握を行 うため, 臨床像の調査を行った。

\section{方法}

S59年からH15年の間に行われた航空医学研究 センターにて航空身体検査 (AME) 全受検した航 空機乗員（全例日本人男性）を対象に，年ごとに 受験者数, 痛風・高尿酸血症罹患, 及び尿酸結 石罹患数, 血清尿酸值, BMI, 等につき調査した。

\author{
岡部 英明 ${ }^{11}$ \\ 上竹大二郎 ${ }^{11}$ \\ 大野 岩男 ${ }^{11}$
}

三浦 靖彦2)

正田 美穂 ${ }^{11}$

津久井一平 ${ }^{21}$

西川 元 ${ }^{1}$

五味 秀穂 ${ }^{11}$

細谷 龍男 ${ }^{11}$

\section{結果}

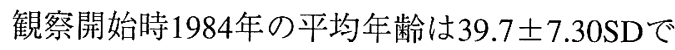
あり, 1999年の平均年齢は44.5土17.2SDであった。 この間有意に平均年齢が上昇していた。BMIは 1984年時22.4土2.14，2003年時23.4土2.20であり， その間徐々に有意な増加を認めた。血清尿酸值 は有意に増加傾向にあった（1988 5.82士 $1.11 \mathrm{mg} / \mathrm{dl}, 19936.26 \pm 1.13 \mathrm{mg} / \mathrm{dl})$. 血清尿酸值 $7.0 \mathrm{mg} / \mathrm{dl}$ を超える痛風・高尿酸血症は 1984 年 $12.8 \%, 2003$ 年 $20.3 \%$ と増加傾向を認めた.

\section{考 察}

AMEは航空機の安全航行を目的としているた め, 検査值が判定基準を超える乗員に対して, 状態改善するまで乗務を禁じている。そのため, 今回の結果で検査值が変動していないのは, 治 療による改善がなされているためと考えられる。 しかし，罹患者数は明らかに増加しており，今 後も痛風・高尿酸血症に対する予防, 加療とい うものが重要である。
1）東京慈恵会医科大学 腎臓・高血圧内科
Yuichirou Yamaguchi, Hideaki Okabe, Hajime Saikawa, Hiroaki Kimura, Daijirou Uetake, Miho Hikita, Hideho Gomi, Kimiyoshi Ichida, Iwao Ohno
2) 航空医学研究センター and Tatsuo Hosoya
Yasuhiko Miura, Ippei Tsukui 


\section{痛風の食生活と生活習慣病の関連, 及び治療としての食事療法の重要性について}

\begin{abstract}
目 的
痛風は食生活と密接な関係のある代謝疾患で ある。痛風患者に食事指導を行い，指導前と指 導後の生活習慣病の各検査值について検討し, 食事療法の重要性を明らかにする。
\end{abstract}

\section{対象及び方法}

痛風患者男性109名を対象とし，食事療法指導 前に食事内容の聞き取り調査をし，指導前後で $\mathrm{BMI}$ ，尿酸（UA）值，総コレステロール（TC）, 中性脂肪 $(\mathrm{TG}), \mathrm{HDL}-\mathrm{C}$, 血糖 (BS), HbA1c, 最高血圧，最低血圧を測定した。対象とする生 活習慣病は, 肥満 (BMI25以上), 高脂血症 (TC 值 $220 \mathrm{mg} / \mathrm{d} 1$ 以上，またはTG值 $150 \mathrm{mg} / \mathrm{d} 1$ 以上)，高 血圧（最高血圧 $130 \mathrm{mmHg}$ 以上，または最低血圧 $85 \mathrm{mmHg}$ 以上), 糖尿病 (BS值 $126 \mathrm{mg} / \mathrm{dl}$ 以上) と した.

\section{データの詳細}

主なデー夕の平均值と標準偏差は以下の通り であった。年齢 $49.5 \pm 12.5$, 総摂取エネルギー

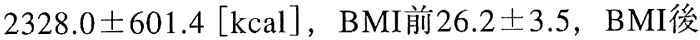
$25.2 \pm 3.4$, TC前 $207.8 \pm 35.4$, TC後196.8 \pm 33.2 , TG前 $222.0 \pm 126.3$, TG後184.3 \pm 120.7 , 最高血圧 前131.2 \pm 19.5 ，最高血圧後 $121.5 \pm 18.1$ ，最低血

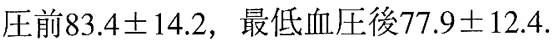

また生活習慣病の指導前後での頻度の推移は, 高脂血症 (85名から65名), 高血圧 (71名から44 名)，糖尿病 (40名から 35 名)，肥满 (70名から 48 名）であった。
岩谷征子橋本純子 上过茂男

鎌谷 直之

\section{結果}

1. 肥満群と非肥満群

痛風，高脂血症，高血圧，糖尿病は肥満と密 接な関係があると考え，肥満群と非肥満群で各 食事内容や各検査值の違いを検討した。食事内 容に差はなかったが，指導前後での尿酸（UA） 值の変化率は非肥満群の方が肥満群より有意に 下がる傾向が見られた。またこの傾向はBMIの 変化率とUA值の変化率の局所回帰曲線からも明 らかであった。これらの結果から肥満群を食事 療法によって非肥満群へ導くことが重要である ことが分かった。ここで変化率は「変化率=（指 導後の值一指導前の值)/指導前の值」で計算し た。

2. 肥満群から非肥満群へ

指導前に肥満群である患者群を対象に，指導 前後で肥满が改善された群を改善群，肥満が改 善されなかった群を不変群とし，両者を比較し た。なお，非肥満から肥満となった患者は見当 たらなかった，両者ではTG值の变化率に有意な 差があり，改善群の方が大きく減少し，高脂血 症頻度も改善群の方が不変群よりも有意に減少 していることがフィッシャーの正確検定で確認 できた。なお，抗高脂血症薬の投与の違いは両 群に差がなく，食事療法期間についても両群に 差はなかった。つまり，食事療法の効果である と期待できる結果となった。またUA值について は有意な差は見られなかったものの, 改善群で は不变群に比べ食事療法指導期間が長くなるに つれてUA值の変化率が大きくなり減少傾向にあ 
ることが局所回帰曲線によって確認された。

\section{結 論}

非肥満群は肥満群よりUA值の減少傾向が見ら れ, 改善群では食事指導期間に比例して減少傾 向にあることが確認された。また生活習慣病に
ついては, 肥泗改善群で高脂血症の改善が多く 見られ, 実際にTG值も減少していることが示さ れた。これらから，食事療法指導は重要である ことが示唆された。 


\section{大豆加工食品等に含まれるプリン体量の測定}

\section{目 的}

高尿酸血症・痛風の治療ガイドラインには, 生活指導として食事療法があげられており，そ の一項目にプリン体の摂取制限が示されている. 筆者らは以前から食品中のプリン体含量を測定 しているが，今回は和食で使用される大豆加工 食品を中心に測定した.

\section{方 法}

各種食品を食品ごとに処理し, 凍結乾燥後, 過塩素酸で加水分解し中和してHPLCの試料とし た. HPLC条件およびキサンチンオキシダーゼと グアナーゼを用いた酵素処理によるピークの同 定は，前法と同様に行った。

\section{結 果}

豆乳はアデニン $(\mathrm{A})$, グアニン $(\mathrm{G})$ ，ヒポキサ ンチン（HX）を合計して $22 \mathrm{mg} / 100 \mathrm{~mL}$ 含むが，豆 腐は $\mathrm{A}, \mathrm{G} か ゙$ 主なプリン体で22～36mg/100gであっ たことから，豆腐を生成する過程でHXは失われ ると考えられる。枝豆は大豆と同様，A，Gを主 にした $48 \mathrm{mg} / 100 \mathrm{~g}$ の含量であり，ピーナッツもほ ぼ同量であった。一方，味噌と滰油はHXを多く

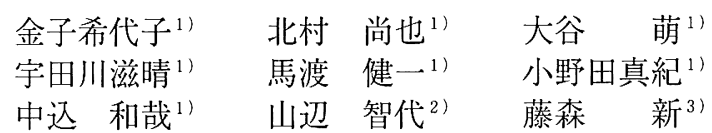

含み, プリン体量としては，奨油 $45 \mathrm{mg} / 100 \mathrm{~mL}$, 味噌48〜 64mg/100gであった。またプリン体を多 く含む野菜と報告されているほうれん草および ブロッコリーを再検討した結果，ほうれん草に $51 \mathrm{mg} / 100 \mathrm{~g}$ (葉の部分), $172 \mathrm{mg} / 100 \mathrm{~g}$ (芽の部分) が，ブロッコリーに70mg/100gが含有されていた。 近年発売されている発泡酒は今までの報告と同 様のプリン体含量であり，プリン体カットビー ルにはほとんどプリン体は含まれていなかった。 プリン体含量が報告されていなかった昆布は乾 燥品で $46 \mathrm{mg} / 100 \mathrm{~g}$, 明太子 $159 \mathrm{mg} / 100 \mathrm{~g}$ であった. さらに，茹でる操作による比較も行ったが，豆 腐，ほうれん草，ブロッコリーとも茹でること により10〜30\%のプリン体が失われていた。ま た調味料で煮ることによりかなり増加すること を確認した。

\section{結 論}

今回測定した食品には，プリン体含量が多い (200〜300mg/100g) と分類されるものはなかった が, 推奨される1日のプリン体摂取量は $400 \mathrm{mg}$ あることから，これらの食品でも総量には注意 する必要があると考えられる。
1 ) 帝京大学薬学部薬品分析学教室

2 ) 帝京大学 医学部 中央機器・R I 室

3 ) 帝京大学 医学部 内科学教室
Kiyoko Kaneko, Naoya Kitamura, Megumi Ohtani, Shigeharu Udagawa, Ken-ichi Mawatari, Maki Onoda and Kazuya Nakagomi

Tomoyo Yamanobe Shin Fujimori 


\section{痛風を含む高尿酸血症患者を対象とした新規キサンチンオキシダーゼ・キサンチンデヒドログナーゼ阻害薬

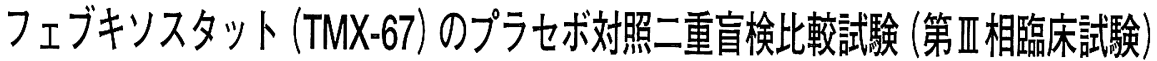

\section{目 的}

フェブキソスタットは，非プリン骨格を有す る特異的なキサンチンオキシダーゼ・キサンチ ンデヒドロナーゼ阻害薬であり, その阻害様式 はアロプリノールと異なる。今回，痛風を含む 高尿酸血症患者を対象にプラセボ対照二重盲検 比較試験を実施し，フェブキソスタット（20, $40 \mathrm{mg} /$ 日）の用量反応性及び有効性と安全性を比 較検討した。

\section{方法}

103例の痛風を含む高尿酸血症患者を対象と し，被験者をプラセボ群 (34症例)，フェブキソ スタット $20 \mathrm{mg}$ (35症例) 及び $40 \mathrm{mg}$ 群 (34症例) へ 無作為に割り付け，導入期にプラセボ群にはプ ラセボ，フェブキソスタット群にはフェブキソ スタット 10mgを1日 1 回 2 週間服薬させた。引 続き治療期にプラセボ群にはプラセボ，フェブ キソスタット群にはフェブキソスタット $20 \mathrm{mg}$ 又 は40mgを 1 日 1 回 6 週間服薬させた。

\section{結 果}

服薬 8 週後の血清尿酸值 $6 \mathrm{mg} / \mathrm{dL}$ 以下達成率 は，プラセボ $0.0 \%$ に対しフェブキソスタット

\begin{tabular}{|c|c|c|c|c|}
\hline 直之") & 藤森 & 新 ${ }^{2)}$ & 波田 & 壽一3) \\
\hline 龍男 ${ }^{4}$ & 松澤 & 佑次 ${ }^{51}$ 6) & 上田 & 孝典 ${ }^{71}$ \\
\hline 山中 寿 ${ }^{11}$ & 加藤 & 隆一81 & & \\
\hline
\end{tabular}

20mg，40mg群で各々 45.7\%（P=0.006）及び91.2\% $(\mathrm{P}<0.001)$ であり，服薬開始前に対する 8 週後 の血清尿酸值変化率は，プラセボvs.フェブキソ スタット $20 \mathrm{mg}, 40 \mathrm{mg}$ 群で各々 -0.9 vs. $-28.7 \%$ $(\mathrm{P}<0.001),-0.8$ vs. $-44.8 \%(\mathrm{P}<0.001)$ であっ た。痛風患者における血清尿酸值低下作用は高 尿酸血症患者と同程度であり，尿酸排泄低下型 （混合型を含む）及び非尿酸排泄低下型（尿酸産 生過剩型, 正常型) に扔いても同程度の血清尿酸 低下作用がみられた。安全性評価結果は，いず れの用量に抢いても臨床上問題となる重篤な有 害事象は認められず，用量依存的な有害事象の 増加傾向もなかった。

\section{結 論}

フェブキソスタット $(20,40 \mathrm{mg} /$ 日) は, 痛風を 含む高尿酸血症患者において用量依存的な血清 尿酸值低下作用を示した。また，臨床上問題と なる有害事象は認められなかった。以上のこと から，フェブキソスタットは痛風または高尿酸 血症患者の治療に対し有効でかつ安全性の高い 薬荗であることが示された。
1) 東京女子医科大学膠原病りウマチ痛風センター
2 ) 帝京大学医学部内科
3 ) 兵庫医科大学総合内科
4 ) 東京慈恵会医科大学腎臓・高血圧内科
5) 大阪大学
6 ) (財) 住友病院
7 ) 福井大学医学部第 1 内科
8 ）慶応義熟大学

Naoyuki Kamatani, Hisashi Yamanaka

Shin Fujimori

Toshikazu Hada

Tatsuo Hosoya

Yuji Matsuzawa

Yuji Matsuzawa

Takanori Ueda

Ryuichi Kato 


\section{痛風を含む高尿酸血症患者を対象とした新梘キサンチンオキシダーゼ・キサンチンデヒドロゲナーゼ阻害薬

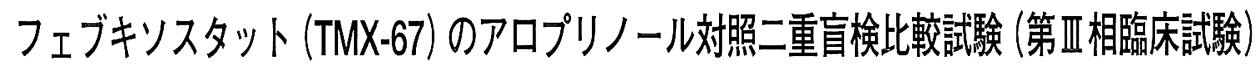

\begin{tabular}{|c|c|c|c|c|c|}
\hline & 直之1) & 藤森 & 新 $^{2)}$ & 波田 & 壽一3) \\
\hline 細 & 龍男 4) & 松澤 & 佑次 ${ }^{5)}$ 6) & 上田 & 孝典 ${ }^{71}$ \\
\hline 山中 & 寿 $^{1)}$ & 加藤 & 隆一8) & & \\
\hline
\end{tabular}

目的

フェブキソスタットは，非プリン骨格を有す る特異的なキサンチンオキシダーゼ・キサンチ ンデヒドロナーゼ阻害薬であり, その阻害様式 はアロプリノールと異なる。今回，痛風を含む 高尿酸血症患者を対象にアロプリノール対照二 重盲検比較試験を実施し,フェブキソスタット (40mg/日) の有効性と安全性をアロプリノール (200mg/日) と比較検討した。

\section{方法}

256例の痛風を含む高尿酸血症患者を対象と し，被験者をフェブキソスタット群（128症例） もしくはアロプリノール群 (128症例) へ無作為 に割り付け, 導入期にフェブキソスタット群に はフェブキソスタット $10 \mathrm{mg}$ を 1 日 1 回, アロプ リノール群にはアロプリノール 100 mgを1日 1 回12日間服薬させ，引続き治療期間にフェブキ ソスタット群にはフェブキソスタット $40 \mathrm{mg}$ を 1 日 1 回, アロプリノール群にはアロプリノール $100 \mathrm{mg}$ を 1 日 2 回44日間服薬させた。

\section{結 果}

服薬開始前に対する服薬開始 8 週後の血清尿 酸值変化率は，フェブキソスタット群，アロプ リノール群で各々 $-40.5,-33.9 \%(\mathrm{P}<0.001)$ であ り, 血清尿酸值 $6 \mathrm{mg} / \mathrm{dL}$ 以下達成率は, 各々 82.0 , 69.0\%（P=0.019）であった。尿酸排泄低下型（混 合型を含む) 及び非尿酸排泄低下型（尿酸産生過 唾型，正常型）における服薬開始 8 週後の血清尿 酸值変化率はフェブキソスタット群で-41.3及び41.4\%，アロプリノール群で-34.7及び-34.4\%で あり，病型間に差は認められなかった。また， 副作用発現率はフェブキソスタット群 $8.6 \%$, ア ロプリノール群 $11.0 \%$ であったが，いずれの群に おいても重篤な副作用は認められなかった.

\section{結 論}

フェブキソスタット $(40 \mathrm{mg} /$ 日) は, アロプリ ノール (200mg/日) に比較して, より強い血清尿 酸值低下作用を示した。また安全性に関しては, 各群とも重篤な副作用は認められなかった。以 上のことから，フェブキソスタットは痛風また は高尿酸血症患者の治療に対し有効でかつ安全 性の高い薬剤であることが示された。
1) 東京女子医科大学膠原病リウマチ痛風センター
2) 帝京大学医学部内科
3 ) 兵庫医科大学総合内科
4 ) 東京慈恵会医科大学腎臓・高血圧内科
5) 大阪大学
6 ) (財) 住友病院
7 ) 福井大学医学部第 1 内科
8 ) 慶応義塾大学

Naoyuki Kamatani, Hisashi Yamanaka

Shin Fujimori

Toshikazu Hada

Tatsuo Hosoya

Yuji Matsuzawa

Yuji Matsuzawa

Takanori Ueda

Ryuichi Kato 


\section{新規キサンチンオキシダーゼ・キサンチンデヒドロゲナーセ阻害剤フェブキソスタット(TMX-67)は， 高尿酸血症の病型によらず尿酸低下作用を発揮する～PK/PDモデル解析による考察}

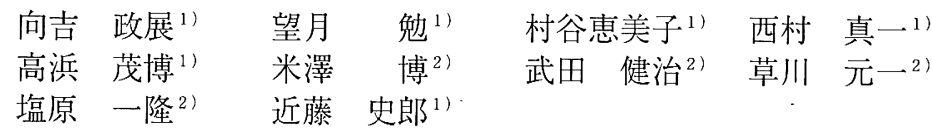

\begin{abstract}
目 的
フェブキソスタット（TMX-67）は，キサンチ ンオキシダーゼ・キサンチンデヒドロナーゼ阻 害薬であり, 痛風を含む高尿酸血症患者を対象 とした臨床試験において, 尿酸産生過剰型及び 尿酸排泄低下型（混合型を含む）の何れの病型の 患者においても血清尿酸低下作用を示した。今 回我々は，フェブキソスタットが病型によらず 尿酸低下作用を発現することに関して，母集団 PK/PDモデル解析による考察を行った.
\end{abstract}

\section{方法}

血中フェブキソスタットの濃度を表わすモデ ル (PKモデル) として2-コンパートメントモデル を，血中尿酸濃度及びキサンチン濃度を表わす モデル（PDモデル）としてフェブキソスタットの 作用メカニズムに従い間接作用モデルを選び, $\mathrm{Ph} 1$ デー夕を基に解析ソフトウェア (NONMEM) を用いて母集団パラメー夕を推定した。このパ ラメータを用いて血中尿酸濃度の推移をシミュ レーションし, Ph1実測值と比較した。次に本モ デルにおいて，尿酸産生過剩型ではキサンチン 産生速度を大きく，尿酸排泄低下型では尿酸ク リアランスを小さくすることで両病型のPDパラ
メータを設定した。これらのパラメータを用い て，フェブキソスタット投与時の血中尿酸濃度 の推移をそれぞれシミュレーションし，両病型 での効果を比較した。更に，Ph2実測值との比較 を行った。

\section{結果及び考察}

$\mathrm{Ph} 1$ データから推定したPK/PDパラメータを用 いてシミュレーションした血中尿酸濃度推移は $\mathrm{Ph} 1$ 実測值とよく一致し, 構築したPK/PDモデル が妥当であることが確認出来た。また，尿酸産 生過剩型及び尿酸排泄低下型を想定し設定した $\mathrm{PD}$ パラメータを用いてフェブキソスタット投与 時の血中尿酸濃度をシミュレーションした結果, 投与開始後数日までは尿酸産生過剰型の方が尿 酸濃度は早く低下する傾向が見られたものの, 定常状態での尿酸濃度は何れの病型でもほぼ同 様であった。更に, シミュレーションの結果と $\mathrm{Ph} 2$ の実測值を比較した結果，導入期間及び治療 期間の何れの用量でも，よく一致することが示 唆された。 以上のことから，フェブキタットは 尿酸産生過剩型及び尿酸排泄低下型の何れの病 型においても，ほぼ同様な尿酸低下作用を示す ことがPK/PDモデル解析から支持された。
$1 ）$ 帝人ファーマ (株) 医薬開発研究所
2 ）帝人ファーマ(株) 医薬第 1 開発部

Masanobu Mukoyoshi, Tsutomu Mochizuki, Emiko Muratani, Shin-ichi Nishimura, Shigehiro Takahama, Shiro Kondo Hiroshi Yonezawa, Kenji Takeda, Gen-ichi Kusakawa and Kazutaka Shiobara 


\section{新規キサンチンオキシダーゼ阻害薬 Y-700 反復投与後の Pharmacokinetics/Pharmacodynamics (PK/PD) について}

\begin{abstract}
背景および目的
アロプリノールの薬物治療の問題点を改善す るために, 現在, 非プリン構造を有し, 非腎排 泄型の新規キサンチンオキシゲナーゼ阻害薬 1[3-cyano-4- (2,2- dimethylpropoxy) phenyl] -1Hpyrazole-4-carboxylic acid（Y-700）を開発中であ る.第37回日本痛風・核酸代謝学会総会にて, 単回投与後の Pharmacokinetics/Pharmacodynamics （PK/PD）について報告した. 今回，Y-700を健康 成人男子に 1 日 1 回反復経口投与して, 血漿中 および尿中未変化体濃度と尿酸, キサンチンお よびヒポキサンチン濃度を指標としたPK/PDにつ いて検討した。
\end{abstract}

\section{方 法}

$\mathrm{Y}-700$ 錠を健康成人男子(被験者数は各群 $\mathrm{n}=6$ ) に 10 日間, 1 日 1 回, 朝食後 30 分に反復経口投 与した。投与量は $30 \mathrm{mg}$ (投与前の血清尿酸值 : $5.55 \pm 1.36 \mathrm{mg} / \mathrm{dL}$ )， $60 \mathrm{mg}$ (投与前の血清尿酸 值： $5.86 \pm 0.68 \mathrm{mg} / \mathrm{dL}$ ) 拉よびプラセボ（投与前 の血清尿酸值： $5.92 \pm 0.85 \mathrm{mg} / \mathrm{dL}$ ) とした. 血漿 中および尿中のY-700, キサンチンおよびヒポキ サンチン濃度はHPLC法で測定した。尿酸濃度は ウリカーゼ法を用いて測定した。

\section{結 果}

因果関係の否定できない有害事象として, 主 に腹痛, 下痢などの消化器症状が認められたが,
山田一磨呂 ${ }^{11}$ 筬島 智則 ${ }^{11}$ 亀澤 美穂 ${ }^{11}$
山中

いずれの所見も軽度で処置を要することなく消 失した。血漿中Y-700濃度推移は投与後 4 日目に 定常状態に到達した。定常状態に扔ける全ての 被験者の $\mathrm{t}_{\max }$ は 4 時間であり, $\mathrm{C}_{\max }$ の変動係数は 20\%前後であったことから, 吸収の個体間変動は 小さかった。投与量で除した $\mathrm{C}_{\max }, \mathrm{AUC}_{0-244}$ 值に有 意差を認めなかった. $\mathrm{t}_{1 / 2}$ は30 mg投与群で33.4時 間， $60 \mathrm{mg}$ 投与群で30.2時間であった．Y-700の尿 中排泄率はいずれも $2 \%$ 未満であった。グルクロ ン酸抱合体として約30\%尿中に排泄された，血清 中尿酸值は30 mg投与群では第 4 日目, $60 \mathrm{mg}$ 投 与群では第 5 日目に定常状態に到達した。最終 投与後24時間の血清中尿酸值は, $30 \mathrm{mg}$ 投与群で $2.88 \pm 0.91 \mathrm{mg} / \mathrm{dL}(\Delta$ 值 : $-2.67 \mathrm{mg} / \mathrm{dL}), 60 \mathrm{mg}$ 投 与群で $1.82 \pm 0.26 \mathrm{mg} / \mathrm{dL}$ ( $\Delta$ 值 : $-4.03 \mathrm{mg} / \mathrm{dL})$ で あった。プラセボ群の血清中尿酸值は $5.92 \pm 0.66$ $\mathrm{mg} / \mathrm{dL}$ あ゙あった，Y-700の $\mathrm{AUC}_{0-241}$ 值と血清中尿酸 值の $\Delta$ 值との相関係数は約 $-0.8 て ゙ あ り$, 負の相関 を認めた. $30 \mathrm{mg}$ および $60 \mathrm{mg}$ 投与群の尿酸クリ アランスはプラセボ投与群と同程度であった。 尿中キサンチンおよびヒポキサンチン排泄量は, 投与第 2 日目に定常状態に到達した。キサンチ ン, ヒポキサンチンの尿中排泄量は用量反応的 に増加した。

\section{結 語}

Y-700を健康成人男子に 1 日 1 回反復経口投与 すると, 初回投与後 4 日目までに定常状態に到
1) 三菱ウェルファーマ株式会社 創薬本部

2 ) 東京女子医科大学付属膠原病リウマチ痛風センター
Ichimaro Yamada, Tomonori Osajima and Miho Kamezawa

Hisashi Yamanaka 
達し，投与量 $60 \mathrm{mg}$ まで用量比例性を示した，定 常状態における未変化体の尿中排泄率は2\%未満 であり，非腎排泄型を示した。安全性に関して は特に問題となる所見は認められなかった。ま
た，Y-700は 1 日 1 回投与において強力且つ持続 的な尿酸低下作用を示した。血漿中未変化体濃 度と尿酸低下作用の間に良好な負の相関を認め た。 


\section{ベンズブロマロン継続服用患者における未変化体ベンズブロマロンと 代謝物6-ヒドロキシベンズブロマロンの血中濃度測定}

\begin{abstract}
目 的
尿酸排泄促進薬のベンズブロマロン (BBR) は 肝臓の薬物代謝酵素CYP2C9によって主に6-ヒド ロキシベンズブロマロン（6-OHBBR）に代謝され るが (新薬と臨床53:682,2004), 反復投与時の未 変化体BBR㧍よび代謝産物6-OHBBRの血中濃度 を検討した報告はない。今回，BBR継続服用中 の患者においてBBRおよび6-OHBBR濃度を測定 し，若干の知見を得たので報告古る。
\end{abstract}

\section{方 法}

2004 年 2 月から 6 月の間に帝京大学病院で BBR治療中の患者44例から得た血液検体につい てLC/MS/MSを用いてBBR㧍よび6-OHBBR濃度 を測定した。 BBRの投与量別の患者数は $12.5 \mathrm{mg} /$ 日が 3 例（当日服薬 3 例）, $25 \mathrm{mg} /$ 日が 21 例（当日 服薬14例)，50mg/日が12例（当日服薬10例）で, BBR25mgとアロプリノール $100 \mathrm{mg}$ の併用投与が 8 例 (当日服薬 1 例) であった.

\section{結 果}

$12.5 \mathrm{mg} /$ 日， $25 \mathrm{mg}$ /日，50mg/日拉よび併用投与

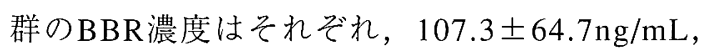
$392.6 \pm 504.9 \mathrm{ng} / \mathrm{mL}, 804.4 \pm 708.9 \mathrm{ng} / \mathrm{mL}, 23.9 \pm$ $67.5 \mathrm{ng} / \mathrm{mL}$ であり，投与量に比例してBBR濃度は 増加したが, 併用投与群のBBR濃度は $12.5 \mathrm{mg}$ /日 投与群よりも低值であった。各群の6-OHBBR濃

\author{
藤森 新 ${ }^{11}$ 及川 寿浩 ${ }^{2}$ 小片 展之 ${ }^{11}$ \\ 渡辺 浩之 ${ }^{11}$ 山内 俊一1) 金子希代子 ${ }^{31}$
}

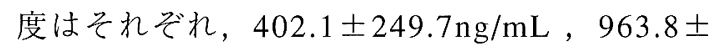
$452.0 \mathrm{ng} / \mathrm{mL}, \quad 1383.5 \pm 431.4 \mathrm{ng} / \mathrm{mL}, 739.6 \pm 212.3$ $\mathrm{ng} / \mathrm{mL}$ で，BBRと同様に投与量に比例して血中濃 度は増加したが，併用投与群では $25 \mathrm{mg} /$ 日投与群 よりも低值であった。これらを検査日の服薬状 況別に再検討すると, 服用量の如何にかかわら ず当日服薬していない患者のBBR濃度は11.4-30.5 $\mathrm{ng} / \mathrm{mL}$ で痕跡程度であったが，6-OHBBRに関し ては当日服薬していない患者においても服薬量 に応じて $663.3 \pm 315.1 \mathrm{ng} / \mathrm{mL}(25 \mathrm{mg} /$ 日), $1160.0 \pm$ $784.2 \mathrm{ng} / \mathrm{mL}(50 \mathrm{mg} /$ 日)， $670.9 \pm 92.3 \mathrm{ng} / \mathrm{mL}$ (併用 投与）と当日服薬患者の $50 \%$ 程度の血中濃度が認 められた。併用投与群で当日服薬している患者 の6-OHBBR濃度は $1220.5 \mathrm{ng} / \mathrm{mL}$ で，25mg/日投与 群の $1114.0 \pm 442.3 \mathrm{ng} / \mathrm{mL}$ と大差なかった. 投与群 別の血清尿酸值は $5.8 \pm 0.7 \mathrm{mg} / \mathrm{dL}(12.5 \mathrm{mg} /$ 日), $6.0 \pm 1.1 \mathrm{mg} / \mathrm{dL}(25 \mathrm{mg} /$ 日), $6.0 \pm 0.9 \mathrm{mg} / \mathrm{dL}(50 \mathrm{mg} /$ 日), $5.6 \pm 0.6 \mathrm{mg} / \mathrm{dL}$ (併用投与) で 4 群間で有意 差はなかった。尿酸排泄率FEUAはBBR濃度とは 相関せず $\left(\mathrm{r}^{2}=0.028, \mathrm{p}=0.28\right), \quad 6-O H B B R$ 濃度と の間に正の相関がみられた $\left(\mathrm{r}^{2}=0.225, \mathrm{p}=0.001\right)$.

\section{考察}

BBRと6-OHBBRはいずれも投与量に比例して 血中濃度の増加がみられた。両薬物の生物学的 半減期の違いに従って, 当日服薬していない患 者の血中にはBBRはほとんど存在しないが，6-
1 ) 帝京大学医学部内科

2）鳥居薬品株式会社医薬情報部

3 ) 帝京大学薬学部薬品分析学
Shin Fujimori, Nobuyuki Ogata, Hiroyuki Watanabe and Toshikazu Yamanouchi Toshihiro Oikawa Kiyoko Kaneko 
OHBBR は当日服薬していなくても, 当日服薬患 者の $50 \%$ 程度の血中濃度が存在した. FEUAとの 関係からBBR継続投与中の尿酸排泄作用は6OHBBRに依存することが確認された。併用投与
群における6-OHBBR 濃度が, BBR25mg/日投与 群よりも低值であった理由はアロプリノーによ る薬物相互作用の結果ではなく, 当日の服薬状 況の違いであろうと考えられた。 


\section{ベンズブロマロンおよび 6 -水酸化ベンズブロマロンのURAT1に 対する阻害作用の検討}

及川 寿浩 ${ }^{1)}$ 石川 宗作 ${ }^{21}$ 遠藤 仁 $^{31}$

目 的

尿酸排泄促進剂であるベンズブロマロンは， 尿酸トランスポーターURAT1による尿酸の取り 込みを強く阻害し，その結果，腎臓における尿 酸の再吸収を抑制することにより尿酸の尿中排 泄を促進し，血中尿酸值を低下させると考えら れている．またベンズブロマロンは経口投与後, 肝臓において 6-水酸化ベンズブロマロンに代謝 され，尿中には 6-水酸化ベンズブロマロンが持 続的に排出される一方, ベンズブロマロンは尿 中にほとんど認められないことが明らかになっ ている.

今回我々は, ベンズブロマロンの薬効機序解 明の一環として，6-水酸化ベンズブロマロンの URAT1に対する阻害作用を検討し, 薬物動態の 観点から尿酸排泄促進作用における 6-水酸化べ ンズブロマロンの寄与について若干の考察を加 えた。

\section{方 法}

MDCK細胞にURAT1 cDNAを組み込んだ安定 発現細胞（MDCK-URAT1）を用いて, 種々の濃 度でベンズブロマロンおよび 6-水酸化ベンズブ ロマロンを添加した際の $\left[{ }^{14} \mathrm{C}\right]$ urateの取り込み を測定し， $\mathrm{IC}_{50}$ 值を算出した。

\section{結果および考察}

ベンズブロマロンおよび 6-水酸化ベンズブロ マロンは，MDCK-URAT1における $\left[{ }^{14} \mathrm{C}\right]$ urateの 取り込みを濃度依存的に抑制し， $\mathrm{IC}_{50}$ 值はベンズ ブロマロンで $0.0345 \pm 0.003 \mu \mathrm{M}, 6$ - 水酸化ベンズ ブロマロンで $0.20 \pm 0.06 \mu \mathrm{M}$ であった.

以上の様に，6-水酸化ベンズブロマロンはベ ンズブロマロンに比べて若干弱いながらも URAT1に対して阻害作用を示したことから，6水酸化ベンズブロマロンはベンズブロマロン経口 投与時の尿酸排泄促進作用に寄与し, 特に作用の 持続性に果たす役割が大きいものと考えられた。
1）鳥居薬品株式会社

2) 株式会社ヒューマンセルシステムズ

3 ) 杏林大学 医学部 薬理学教室
Toshihiro Oikawa

Sosaku Ishikawa

Hitoshi Endou 


\section{液体クロマトグラフ質量分析装置による 血清中の尿酸ナトリウム結晶吸着タンパク質の分析}

岩田 英信 ${ }^{11}$ 金子 希代子 ${ }^{21}$

\section{目 的}

尿酸ナトリウム結晶に選択的に吸着する血清 中のタンパク質を液体クロマトグラフ質量分析 装置で分析し、同定する。

\section{方 法}

一人の非痛風者の血清をそのまま、あるいは デキストラン硫酸・塩化マグネシウム沈殿法でリ ポタンパク質を除去したのち、McCartyと Faires の方法で作製した尿酸ナトリウム結晶に加え、 $37^{\circ} \mathrm{C}$ で 1 時間インキュベートした。結晶を尿酸 ナトリウム飽和生理食塩液で数回洗浄したのち、 透析膜に入れて純水透析することで完全に溶解 した。

濃縮した尿酸ナトリウム結晶吸着タンパク質 をSDS-ポリアクリルアミドゲル電気泳動 (SDSPAGE）にかけ、クマジブルーで染色されたバン ドを切り出した。トリプシンでゲル内消化した のち、液体クロマトグラフ質量分析装置でペプ チド分析を行い、得られたアミノ酸配列をタン パク質データベースで検索した。

\section{結 果}

SDS-PAGEに抢ける分子量と、データベース検 索結果を表に示した。

\begin{tabular}{|c|c|c|}
\hline & 血清 & リポタンパク質除去血清 \\
\hline $150 \mathrm{kDa}$ & 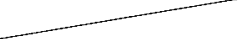 & 補体H因子 \\
\hline $80 \mathrm{kDa}$ & $\begin{array}{c}\text { アンチトロンビン II } * 1 \\
\text { プロトロンビン*1 } \\
\text { アポタンパクB100 }\end{array}$ & \\
\hline $66 \mathrm{kDa}$ & $\begin{array}{c}\text { アポタンパクB100 } \\
\text { Ig重鎖※4 }\end{array}$ & $\begin{array}{c}\text { 補体C3 } * 2 \\
\operatorname{Ig} \text { 重鎖 } * 4 \\
\text { アルブミン } \\
\text { ヒスチジンリッチ糖タンパク質 }\end{array}$ \\
\hline $55 \mathrm{kDa}$ & $\begin{array}{l}\text { アンチトロンビンIII } \\
\text { アポタンパクB100 }\end{array}$ & \\
\hline $28 \mathrm{kDa}$ & $\begin{array}{r}\text { 補体C3 } ※ 3 \\
\text { Ig軽鎖 } ※ 5\end{array}$ & \\
\hline
\end{tabular}

※ 1 : トロンビン部分のペプチドのみが検出されたこと から，トロンビン-アンチトロンビン III複合体と考 えられた。

※ 2：C3bの $\alpha$ 鎖N末端側 (C3dgを含むがC3fよりC末端側 は含まない) と， $\beta$ 鎖のほぼ全長に渡って分布す るペプチドが検出されたことから $\mathrm{iC} 3 \mathrm{~b}$ と考えられ た.

※ $3: \mathrm{C} 3 \mathrm{~b} の \alpha$ 鎖N末端側 (C3dgよりC末端側は含まない) と, $\beta$ 鎖のC末端側のペプチドが検出されたことか らC3cと考えられた。

※ 4 : いずれの血清からも $\mu$ 鎖定常部と合致するペプチ ドのみが検出された。

※ $5 ： \kappa$ 鎖定常部と合致するペプチドのみが検出された.

\section{結 論}

尿酸ナトリウム結晶に吸着した血清タンパク 質を分析し，凝固系タンパク質ではアンチトロ ンビン III とトロンビン-アンチトロンビン III 複合 体，補体系タンパク質では $\mathrm{iC} 3 \mathrm{~b}, \mathrm{C} 3 \mathrm{bc}$ と H因子, 抗体ではIgMを同定した。
1) 愛媛大学 医学部 看護学科

2 ) 帝京大学薬学部 薬品分析室
Hidenobu Iwata

Kiyoko Kaneko 


\section{微小領域 X線回折装置およびLC-MSを用いた尿酸結石の分析}

目的

痛風・高尿酸血症や腎性低尿酸血症では尿路 結石の合併が多い。私達は, 微小領域 X 線回折 装置を用いて尿酸結石を微細に調べた後, 液体 クロマトグラフ-質量分析装置 (LC-MS) を用い て尿酸結石中のタンパク質成分の分析を行った.

\section{方法}

微小領域X線回折装置 (JEOL JDX-8030T) を用 いて結石外辺部や断面部を非破壊的に分析した。 次に結石を粉砕して $\mathrm{KCl}$ ，ギ酸，グアニジン， EDTAでタンパク質を抽出し, 電気泳動を行った. ゲルから切り出したスポットをトリプシン処理 して，LC-MS（サーモクエスト LCQ DECA, AMR MAGIC2002）を用いたMS/MS分析からタン パク質解析を行った。いずれもデータベースと の比較により物質を同定した. $\begin{array}{lrlll}\text { 山辺 } & \text { 智代 }{ }^{1)} & \text { 金子希代子 }{ }^{21} & \text { 藤森 } & \text { 新 }^{31} \\ \text { 清水 } & \text { 徹 }^{4)} & & \end{array}$

\section{結 果}

微小領域 X線回折分析の結果, 結石 $\mathrm{A}$ は均一 な尿酸結石で, LCMS 分析からアルブミン, ウ ロモジュリン, Ig G, リゾチームが検出された. 尿路結石 B は外辺部が尿酸から成り，内面部に はシュウ酸カルシウム 1 水和物も含まれており, LCMS分析の結果, 上記と共通のアルブミン, ウ ロモジュリン, リゾチームの他, Ca-binding protein, デフェンシンが検出された.

\section{考察}

アルブミン，ウロモジュリン，Ig Gは結石のマ トリックスとしてよく知られている。Ca-binding protein はカルシウム結合性のタンパク質である ため，カルシウム成分を有する結石Bから検出 されたと考えられる。リゾチームとデフェンシ ンの尿路結石における役割にも興味が持たれる. 個々の結石から情報が得ることは，症例や病態 の解析に役立つと考えられる。
1) 帝京大学医学部 中央機器 - R I 室

2) 帝京大学 薬学部薬品分析学教室

3 ）帝京大学医学部 内科学教室

4) みどりケ丘病院 外科
Tomoyo Yamanobe

Kiyoko Kaneko

Shin Fujimori

Toru Shimizu 


\section{痛風における腎結石の有病率}

\section{背景・目的}

尿路結石は, 痛風の合併症の中でも尿酸が直 接関与する重要な病態であるが，その臨床的な evidenceは意外と少なく, 有病率でさえ正確に把 握されていない. その理由として, 痛風の発症 は偶発的であり臨床現場から実態が捉えにくい ことに加えて, 合併する結石はX線陰性の尿酸結 石の比率が高いこともあって, 超音波検査のほ かにスクリーニングを行う適切な方法がなかっ たことがあげられる。しかしながら近年，スキ ヤンスピードが速く分解能の優れたマルチスラ イスCTが開発され, 従来型CTでは困難とされて いた $1 〜 2 \mathrm{~mm}$ の小結石やX線透過性の大きい尿 酸結石も撮影することが可能になった。 そこで, 痛風患者の腎臓をマルチスライス CTを用いて初 診時の結石保有の有無を調查し, 腎結石の有病 率を推定した。

\section{方 法}

最近 3 年間に痛風外来を訪れた 220 名のうち 180例について, 初診直後に 2 列の検出器を有す るマルチスライスCT (GE 横河製・Hi-Speed NX/1) を用いて腎結石の有無を調べた。撮影は 1 回の 息止めで腎臓全体をカバーしうる条件を選び, スライス厚 $2 \mathrm{~mm}$, ヘリカルピッチ 3 で行った。 画像再構成間隔は $3 \mathrm{~mm}$ とした。

\begin{tabular}{|c|c|}
\hline 徹 ${ }^{1)}$ & 今西 \\
\hline
\end{tabular}

\section{結 果}

180 例中 37 名 $(20.6 \%)$ に結石と思われる院影 (calculus density) が認められた。

\section{考察・結論}

有病率は「ある一時点に扔いて疾病を有して いる人の割合」であり，初診時のスクリーニン グにより得られた腎結石保有率より痛風患者の 腎結石の有病率を類推することができる。マル チスライスCTで認められるX 線陽性の異常所見 には，(1) 腎盂の周辺部に見られる高密度の点状 の陰影 (calculus density) と，(2) 明らかにそれよ $り$ density の低い斑状の陰影 (high density area) の 2 種類がある。後者は乳頭部に散見され, 尿酸 塩など結晶質の沈着である可能性があるものの 結石とは考えにくい. 一方，前者はほとんど腎 孟の辺縁 (腎杯)に出現し結石である可能性が極 めて高い。これを結石とみなすと, 痛風患者の 腎結石の「有病率」は約 $20 \%$ と推定することが できる，CTにより腎結石と診断された症例の約 57\%はいわゆる silent stone であったのに対して, 従来はなんらかの臨床症状を有したものが結石 合併例とされ，「合併率」の対象とされてきた。 結石合併の確認は, リアルタイムの検査ばかり でなく病歴の聴取によって行われたものも多い ので，「合併率」は痛風罹患期間に扔ける「累積 罹患率」を表していると考えてよい.
1）みどりヶ丘病院外科

2) 同 放射線科
Toru Shimizu, Tsutomu Imanishi and Hiroshi Kato Hiroshi Hori 


\section{高中性脂肪血症を合併した痛風患者に対する 高脂血症治療剤投与前後の尿 $\mathrm{pH}$ 検討}

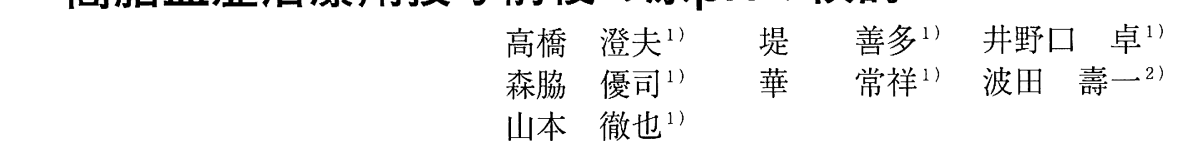

\section{目的}

痛風患者に高中性脂肪血症を伴うことはよく 知られて打り，また，尿 $\mathrm{pH}$ の低下は尿路結石を 誘発する一因と考えられている。昨年, 我々は 痛風患者では血清中性脂肪値, HOMA index 24 時間尿のpH值が逆相関を示すことを発表し，尿 $\mathrm{pH}$ 值にインスリン抵抗性が一部関与している可 能性を示唆した。そこで高中性脂肪を合併した 痛風患者に高脂血症治療剂（フェノフィブレート， ベザフィブレート)の投与前後の 24 時間尿の $\mathrm{pH}$ 值を検討した。

\section{方 法}

高中性脂肪血症を伴った痛風患者27名 [アロプ リノール (Allo) 投与 : $n=14$, ベンズブロマロン (BZB) 投与 : $\mathrm{n}=13]$ にフェフィブレート $300 \mathrm{mg} / \mathrm{day}$ (Feno投与群)を, 18名 [Allo投与： $\mathrm{n}=7$, BZB投与 : $n=11]$ にベザフィブレート $400 \mathrm{mg} / \mathrm{day}$ (Beza投与群) 投与し, 治療前後で尿 酸代謝, 血清脂質および24時間尿 $\mathrm{pH}$ 值などの項 目について比較した.

\section{結 果}

1) 両群とも高脂血症治療剂投与後でBody mass index拉よび尿量は差が認められなかった。
2) 高脂血症治療剂投与後では投与前と比較し て, 両群とも血清中性脂肪は有意に低下し た (Feno投与群 $\mathrm{p}<0.01$, Beza投与群 $\mathrm{p}<$ 0.01 ).

3 ) 高脂血症治療剂投与後では投与前と比較し て, 両群とも尿中 $\mathrm{pH}$ 值が有意に上昇した （Feno投与群 $\mathrm{p}<0.01$ ，Beza投与群 $\mathrm{p}<0.05$ ).

4) 高脂血症治療剂投与後では投与前と比較し て, 血清尿酸值 (SUA) はFeno投与群で有意 な低下が見られたが $(\mathrm{p}<0.01)$, Beza投与群 では有意な低下は見られなかった。また， クレアチニン・クリアランス $(\mathrm{Ccr})$, 尿量は 両群とも治療前後で有意な変化はみられな かった.

\section{考察}

高中性脂肪血症を伴った痛風患者に高脂血症 治療剂を投与後, 有意に尿中 $\mathrm{pH}$ 值が上昇した。 このことは高脂血症治療剤が持つインスリン抵 抗性の改善が一部関与している可能性が示唆さ れ，特に高中性脂肪血症を伴う場合には，尿路 結石を予防する面からも積極的に治療を行った 方が良いと考えられた。
1 ）兵庫医科大学内科内分泌代謝科
Sumio Takahashi, Zenta Tsutsumi, Taku Inokuchi, Yuji Moriwaki Tsuneyoshi Ka and Tetsuya Yamamoto
2 ) 兵庫医科大学
Toshikazu Hada 


\section{全身性の多発関節炎を呈した痛風の一例}

$\begin{array}{llllll}\text { 岡部 英明 } & \text { 山口雄一郎 } & \text { 西川 } & \text { 元 } & \text { 木村 } & \text { 弘章 } \\ \text { 上竹大郎 } & \text { 正田 美穂 } & \text { 五味 } & \text { 秀穂 } & \text { 市田 } & \text { 公美 } \\ \text { 大野 岩男 } & \text { 細谷 龍男 } & & & & \end{array}$

症例は52歳, 男性。主訴は嘔吐, 腹痛。現病 歴は2003年5月 20 日, 嘔吐, 腹痛を自覚し当院救 急室に来院。緊急検査にて血清 Cr $7.8 \mathrm{mg} / \mathrm{d} l$, UA16.9mg/dl, AMY 73IU/1の異常值と緊急腹部 CT検査にて仮性膵囊胞を認め，腎不全，高尿酸 血症および急性膵炎を疑われ緊急入院となった。 大酒家. 32 歳頃に痛風と診断され, 今回入院す る 1 年前から他院で処方されたべネシッド，コ ルヒチンおよびボルタレンを連日内服していた。 32歳頃に高血圧を指摘，40歳時には胆石症にて 胆囊摘出術施行している。家族歴に痛風・高尿 酸血症はなく，血縁婚もなし，身長 $171 \mathrm{~cm}$, 体重 $51 \mathrm{~kg}$, 血圧 $128 / 82 \mathrm{mmHg}$, 脈拍 $66 / \mathrm{min}$, 体温 $36.8^{\circ} \mathrm{C}$. 眼瞼結膜は貧血様, 眼球結膜に黄染なし. 両側肘関節外側部に皮下結節を認めた。心窩部 に圧痛を認めたが，その他神経学的所見を含め 異常所見なし. 入院時の急性膵炎, 腎不全と診 断され, 補液と膵炎治療薬による加療を開始. 第 3 病日，急性荤炎，腎不全は改善傾向たった が， $39^{\circ} \mathrm{C}$ 前後の発熱と CRP $16 \mathrm{mg} / \mathrm{dl}$ 以上の上昇を 認めた。第 5 病日, 血清AMYは正常化し急性膵 炎の増悪は否定的となったが, 両側の手指, 手,
肘, 滕, 足および足趾関節の疼痛, 腫脹, 発赤 を認めた。関節X線上の骨破壊像とRI検査での多 関節への集積像を認め, 膝関節穿刺液内に尿酸 塩結晶を証明したことから全身性の多発性痛風 関節炎と確定診断した。診断後プレドニゾロン （PSL） $15 \mathrm{mg} /$ dayの内服治療を開始したところ， 解熱および関節炎症状の改善, CRPの低下を認 めたが, 痛風発作を数回繰り返すためPSLの減量 が困難であった。第30病日，高尿酸血症の是正 を目的にアロプリノール $100 \mathrm{mg} / \mathrm{day} の 内$ 服治療を 開始した。高尿酸血症の是正が不十分であるた め，第37病日からベンズブロマロン $25 \mathrm{mg} / \mathrm{day}$ 追加し併用療法を開始した。その後, 腎機能の 増悪はなく, 血清UAは8.0mg/dl前後まで改善し たため退院となった。退院後の外来では血清UA が上昇し, 数回の痛風発作を繰り返すためPSLに よる治療の継続を必要とした。多発性痛風関節 炎に対してステロイド薬が奏功したが, 痛風関 節炎の再燃を繰り返し, 痛風腎による腎不全を 合併していることからステロイド薬による治療 の継続を必要とし, 高尿酸血症の是正が非常に 困難であった一例を経験した。
東京慈恵会医科大学腎臓・高血圧内科

Hideaki Okabe, Yuichirou Yamaguchi, Hajime Saikawa, Hiroaki Kimura, Daijirou Uetake, Miho Hikita, Hideho Gomi, Kimiyoshi Ichida, Iwao Ohno and Tatsuo Hosoya 


\section{URAT 1 遺伝子にナンセンス変異を認めた 特発性腎性低尿酸血症の 1 症例}

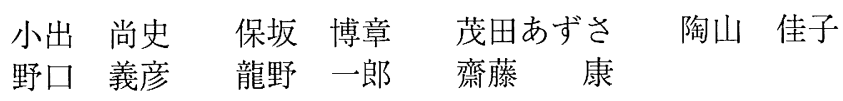

\section{背景・目的}

低尿酸血症を示吉原疾患の中で腎性低尿酸血 症の占める比率は非常に高く，また明らかな基 礎疾患を有さない特発性腎性低尿酸血症と診断 される場合がほとんどである。近年，腎臓尿酸 トランスポーター（URAT1）をコードする遺伝子 （SLC22A12）が同定され，同遺伝子の変異によ る腎性低尿酸血症の発症への関与が注目されて いる。.さらに，腎性低尿酸血症の患者で運動後 に急性腎不全を発症した症例報告が近年増加し ている。今回我々は特発性腎性低尿酸血症と診 断された症例に対し, URAT1遺伝子解析を施行 した。

\section{対象}

症例は45歳，男性. 平成6年より健診にて尿酸 值0.6 1.1 mg/dlを指摘されていた。平成 13 年近医 の健診で低尿酸血症を認め, 精査を勧められ平成 16 年6月 15 日当院紹介受診. 同年8月4日に，低尿 酸血症の精査目的にて当院入院となった，入院時 の尿酸值は $1.1 \mathrm{mg} / \mathrm{dl}$. 運動後急性腎不全の既往は 無く, 低尿酸血症の家族歴は不明であった。また, 2次性の低尿酸血症を疑う所見を認めなかった。

\section{方 法}

従来から知られる4 component modelに基づく腎 性低尿酸血症の病型分類を施行.さらに，インフ ォームドコンセント後, 患者末梢血よりgenomic
DNAを抽出し，ダイレクトシークエンスを行い URAT 1 遺伝子の10個のexonの解析を行った.

\section{結 果}

病型分類目的にてピラジナマイド負荷試験, ベンズブロマイド負荷試験を施行. 次に, URAT 1 遺伝子の解析を施行した。ピラジナマイド負 荷試験ではCUA/Ccrの軽度低下，ベンズブロマイ ド負荷試験ではCUA/Ccrの低下を認めた。特発性 腎性低尿酸血症の分類にて全ネフロン再吸収障 害型と診断した。URAT1遺伝子解析を施行した 所, exon4の774番目塩基にpoint mutationを認め, これにより stop codonとなるナンセンス変異 (nonsense mutation W258X) であることが判明した。また, シークエンスシグナルよりはheterozygousG774Aであ ると診断した。

\section{考察}

同部位の変異は既存の報告と一致し低尿酸血 症を呈することが証明されているが， heterozygousG774A単独で腎性低尿酸血症を呈す るか否かは, その他の環境因子, 遺伝因子の関 与が示唆されている。また, URAT1遺伝子の異 常に伴う腎性低尿酸血症はautosomal recessiveの 可能性が指摘されているが，同遺伝子の機能と 遺伝形質をさらに検討するために，今後同一家 族内に打けるURAT1遺伝子の解析と phenotypeの 比較を行っていく予定である. 


\section{遺伝性低尿酸血症 4 例の臨床経過と遺伝子解析}

目的

遺伝性低尿酸血症は尿細管での尿酸トランス ポーター蛋白であるURAT1の変異により生じる. 頻度としては，0.9\%とされているが，臨床的に 診断される機会は比較的少ないと思われる.

\section{対象・方法}

過去 5 年間で当院で経験した遺伝性低尿酸血症 4 例 5 家系の臨床経過と遺伝子変異について検討 した。また，1例については腎生検を行った。

\section{結 果}

発症は 4 例中 3 例が急速な腎機能低下をもっ て発症し， 2 例は発症前に肉体労働の既往を有 していた。また，その 3 例全例に鎮痛薬を使用 の既往を認めた。

1 例は急速進行性糸球体腎炎・間質性腎炎と の鑑別が困難であったため, 腎生検を施行した。 生検所見では尿細管に部分的な管腔の拡大を認 めた。系球体，尿細管管外には炎症細胞等の浸 潤を認めなかった. 入院後の経過は安静と補液 で全例腎機能は回復し, 腎機能の回復後に著明 な低尿酸血症を認めた。クレアチニンクリアラ

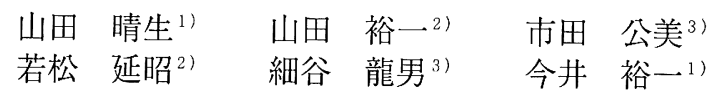

ンスに対する尿酸クリアランスの比は $100 \%$ 以上 を示した。

4 例中 3 例について遺伝子解析を行った。そ の結果 2 例はURAT1の翻訳領域に変異を認めず, 1 例はG774AとG1082Tの複合へテロ接合体であ った.

このG1082Tの変異によりアミノ酸はGly $\rightarrow \mathrm{Val}$ となり, 新規の変異であることが確認できた。

\section{考察}

遺伝性低尿酸血症は臨床的には急性腎不全で 発症する場合が少なくない，その原因としては， 血管攣縮説・尿細管閉塞説などあるが未だに結 論をみていない．本症例で腎不全を示した症例 の全例に鎮痛剂の既往を認めたことは血管鍊縮 説を支持するものであり，また，腎生検で尿細 管の部分的な管腔の拡大は尿細管閉塞説を支持 する結果と思われる。

\section{まとめ}

遺伝性低尿酸血症で腎生検をした症例と新規 な変異を有する症例を経験した。
1) 愛知医科大学 腎臓・膠原病内科

2 ) 愛知県心身障害者コロニー発達障害研究所 遺伝学

3 ）東京慈恵会医科大学 腎臟・高血圧内科
Haruo Yamada, Yuichi Imai Yuichi Yamada, Nobuaki Wakamatsu Kimiyoshi Ichida, Tatsuo Hosoya 


\section{痛風発症における抑制的要因であるURAT1/SLC22A12遺伝子変異}

\section{背景}

痛風の発症には遺伝的要因と環境要因が関与 すると言われている。このうち，遺伝的要因に ついては主に先天代謝異常の原因遺伝子異常や アルコール代謝経路の酵素の遺伝子多型が知ら れているが，検討は比較的少ない。近年，尿酸 トランスポーターとしてURAT1/SLC22A12が発 見され，ヒトの尿酸再吸収の中心的な役割を担 うことが示された。したがって，URAT1は血清 尿酸值の調節に重要な因子である可能性が考え られた。

\section{目 的}

痛風患者群と健常コントロール群のゲノムを用 いた解析により, 痛風の発症とURAT1/SCL22A12 遺伝子との関連を検討した.

\section{対象と方法}

当センターに通院中で，アメリカリウマチ協 会の痛風診断基準を満たす男性痛風症例185例と Parma SNP consortiumに登録された健常コントロ ール，男性594人女性386人を対象とした。

インフォームドコンセント後，末梢血よりゲ ノムDNAを抽出し，これらのゲノムDNAを用い, TaqMan法を用いてURAT1/SLC22A12遺伝子にお ける 7 ケ所のSNPについて遺伝子型を決定した。 このなかで, G774Aは変異により stop codonが生 じ, URAT1の機能が失われることが報告されて いる.

\begin{tabular}{|c|c|c|c|c|}
\hline 浦野 & 和子"1) & 谷口 & 敦夫 ${ }^{1)}$ & 山中麻里子 ${ }^{1)}$ \\
\hline 山中 & 寿 $^{11}$ & 鎌谷 & 直之"1) & 細山田 真 ${ }^{2)}$ \\
\hline
\end{tabular}

これらの遺伝子型の 2 群間での頻度の差につ いて統計学的解析を行い, 更にコントロール群 について，これらのゲノムに対応するデータべ 一スを用い，検出されたSNPと血清尿酸值との関 連を解析した。

でした。

\section{結 果}

対象とした痛風患者群と男性コントロール群 において年齢分布に有意差はなかった。 BMI・ 中性脂肪值 ·血清尿酸值は痛風患者群で有為に 高值であった。

今回検討した 7 ケ所の多型のうち, G774A変 異において, 痛風患者群・男性コントロール群 ともAA genotypeは認められなかったが, GA genotypeは痛風群に認められず, 男性コントロー ル群では 25 人に認められ，この 2 群間には統計 学的な有意差が認められた。アレルでの比較の 結果もG774A変異に扔けるA アレル頻度は痛風 群は男性コントロール群と比較し有意に低い頻 度であった（表 1 ）。

表 1

\begin{tabular}{lccc} 
& Gout $(\mathrm{n}=185)$ & Male control(n=594) & Gout vs Male controls \\
\hline No. of genotypes $(\%)$ & & & \\
G/G & $185(100.0)$ & $569(95.8)$ & $\mathrm{P}=0.001^{*}$ \\
G/A & $0(0.0)$ & $25(4.2)$ & $\mathrm{OR}=0.000$ \\
A/A & $0(0.0)$ & $0(0.0)$ & $95 \% \mathrm{CI}=0.000-0.496$ \\
No. of alleles(\%) & & & \\
G & $370(100.0)$ & $1163(97.9)$ & $\mathrm{P}=0.002$ \\
A & $0(0.0)$ & $25(2.1)$ & $95 \% \mathrm{CR}=0.00000 .0003$ \\
& & &
\end{tabular}

1 ) 東京女子医科大学附属膠原病リウマチ痛風センター

2 ) 杏林大学薬理学教室
Wako Urano, Atsuo Taniguchi, Mariko Yamanaka, Hisashi Yamanaka and Naoyuki Kamatani Makoto Hosoyamada, Hitoshi Endou 
コントロール群に扔ける血清尿酸值について GA genotype/GG genotypeでの違いを検討した. 男女ともに，GA genotypeをもつ個体ではGG genotypeにくらべ血清尿酸值が有意に低值であっ た（図 1 ).
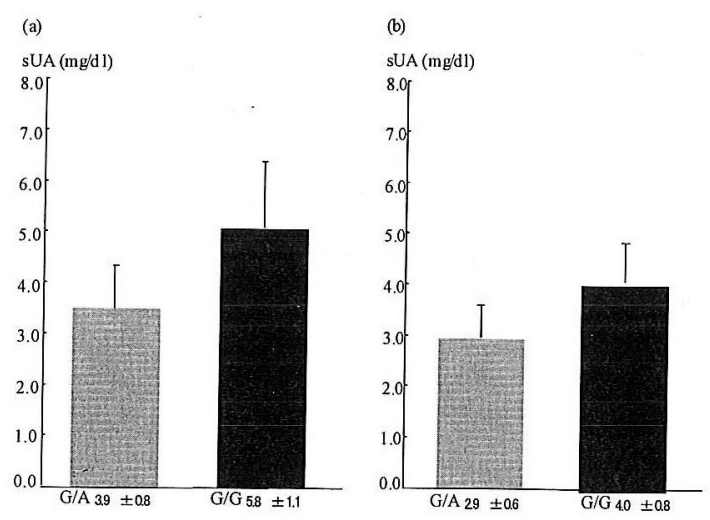

図 1

G774A変異以外の今回検討したSNP6箇所につ いての解析の結果, アレル頻度を比較した結果, 赤字で示すこの $2 つ の$ 変異については, 痛風患
者群・男性コントロール群の 2 群間で統計学的 有意差を認めたが，G774A変異との関連にくら べると関連は弱いと考えられた。

続いて，7箇所のSNPの遺伝子型の結果からア ルゴリズムを用いハプロタイプを推測し，全コ ントロール群, 男性コントロール群, および痛 風患者群のハプロタイプの頻度を検討した結果, G774Aの箇所がGであるハプロタイプは群間でほ とんど差はないが，Aであるハプロタイプは痛風 例には認められず，ハプロタイプの頻度で見て もG774Aのgenotypeの違いが痛風の発症に最も重 要であると考えられた。

\section{考察}

痛風の発症には環境要因と遺伝要因が関与し ており, 環境要因には痛風発症に促進的に作用 するもの，抑制的に作用するものがあると考え られる.今回の研究でURAT1/SLC22A12遺伝子 変異は抑制的な遺伝要因であることが示された． 今後, URAT1についてハプロタイプとの関連を 含めて, さらに詳細な検討が必要と考えられた。 


\section{Uromodulin遺伝子の新たな変異が同定された 家族性若年性高尿酸血症性腎症の一家系例}

家族性若年性高尿酸血症性腎症（Familial Juvenile Hyperuricemic Nephropathy, FJHN) はまれ な常染色体優性遺伝疾患である。若年から高尿 酸血症・痛風を発症し, 高尿酸血症は尿酸排泄 低下型であり，家系内では男女ともに発症する のが特徵である。一方，腎機能が進行性に低下 し，多くは10～20年で末期腎不全に至る．2000 年に原因遺伝子が16番染色体短腕に存在するこ とが示され ${ }^{1)} ， 2002$ 年に本疾患の原因遺伝子とし てUromodulin (UMOD) が同定された ${ }^{2)}$. UMOD の変異はFJHNのほかに髄質囊胞腎, 系球体囊胞 腎の原因になることが示されており，これらは alleic diseasesと考えられている. 現在までに同定 されたこれらの疾患の原因変異は30を超える。 今回，我々は今まで報告されていないUMODの 変異によって生じたFJHNの一家系を経験したの で報告する。

発端者は14歳男性である（症例 1 )。2003年に 腎機能低下と高尿酸血症を指摘されている(血清 クレアチニン值 $1.21 \mathrm{mg} / \mathrm{dl}$, 血清尿酸值 $11.2 \mathrm{mg} / \mathrm{dl})$. 12歳の妹 (症例 2 ) にも腎機能低下と高尿酸血症 が認められる（血清クレアチニン值 $0.84 \mathrm{mg} / \mathrm{dl}$, 血 清尿酸值 $8.2 \mathrm{mg} / \mathrm{dl})$. 家系内に高尿酸血症・腎機 能低下症例を認める.インフォームドコンセン 卜を得た後, 症例 1,2 の末梢血からゲノム DNA を採取し，UMODのexon 4, 5 をPCR増幅した後, PCR産物を直接シーケンシングした。その結果, 症例 1, 2 とも exon 4 にg.1990C > T変異が認めら

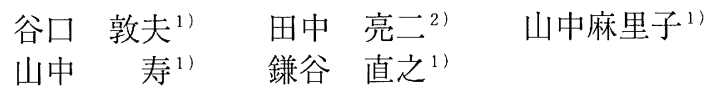

れた。さらに制限酵素Bsg Iを用いたPCR-RFLPに よりシーケンシングの結果を確認した。症例 1 の弟 (13歳)には高尿酸血症・腎機能低下は認め ず，シーケンシングでも変異を認めなかった。こ の変異により185番目のアルギニンがシステイン に変換される，疾患の原因遺伝子となるUMODの 変異はシステイン残基が関与することが多いこ と，ヌクレオチドレベルで同部位の異なる変異が ベルギーで報告されている（g.1990C > A , Arg185Ser) ことなどを考慮すると，本変異はこ の家系のFJHNの原因であると考えられる.

FJHNはまれな疾患であるが，若年発症の高尿 酸血症・痛風例で, 家族歴を有し, 腎機能障害, 家系内での女性の発症などの特徵を有する場合 は遺伝子診断を行う価值があると考えられた。

\section{文献}

1) Kamatani N, Moritani M, Yamanaka $\mathrm{H}$ et al: Localization of a gene for familial juvenile hyperuricemic nephropathy causing underexcretion-type gout to $16 \mathrm{p} 12$ by genome-wide linkage analysis of a large family. Arthritis Rheum 43:925-929, 2000.

2 ) Hart TC, Gorry MC, Hart PS et al: Mutations of the UMOD gene are responsible for medullary cystic kidney disease 2 and familial juvenile hyperuricaemic nephropathy. J Med Genet 39:882-892, 2002.
1) 東京女子医科大学附属膠原病リウマチ痛風センター

2 ）兵庫県立こども病院腎臟内科
Atsuo Taniguchi, Mariko Yamanaka, Hisashi Yamanaka and Naoyuki Kamatani Ryoji Tanaka 


\section{妊娠女性のHPRT部分欠損症}

\begin{abstract}
目 的
女性Hypoxanthine-guanine-phosphoribosyltransferase (HPRT) 完全欠損症は過去に 5 例報告され ているが, 部分欠損症の患者については報告例 がない。またHPRT欠損症の妊娠症例においても 報告例がないので倫理面を含め，検討した。症 例：患者：29歳, 女性. 主訴: 左足関節痛 現病 歴：平成14年 4 月に左側足関節痛が出現したが, 約 2 週間で自然に軽快した。平成15年 1 月に再 び左側関節部に激痛があり，精査加療目的にて 紹介来院となった. 外来通院中妊娠をしたため 遺伝子検索を行った。既往歴：22歳の時尿路結 石. 家族歴：血縁関係で痛風・高尿酸血症の患者 を認めず。現症：来院時は左側関節の腫脹以外の 身体所見に異常を認めず，検査所見：血漿ヒポ
\end{abstract}

$\begin{array}{llllll}\text { 井野口 } & \text { 卓 } & \text { 森脇 } & \text { 優司 } & \text { 高橋 } & \text { 澄夫 } \\ \text { 堤 } & \text { 善多 } & \text { 華 } & \text { 常祥 } & \text { 山本 } & \text { 徹也 }\end{array}$

キサンチン $4.2 \mu \mathrm{mol} / 1$, 血漿キサンチン $1.5 \mu \mathrm{mol} /$ 尿中ヒポキサンチン $9.1 \mu \mathrm{mol} /$, 尿中キサンチン $6.2 \mu \mathrm{mol} / \mathrm{hour}$, 尿中尿酸 $952 \mathrm{mg} / \mathrm{day}$. 赤血球HPRT 活性 $0.52 \mu \mathrm{mol} / \mathrm{gHb} / \mathrm{min}$. 検査所見より HPRT部分 久損症と診断したが通院中に妊娠をしたため患 者本人の遺伝子検査のみならず出生前診断の可 能性も考え, 倫理委員会に諮り, 遺伝子検査を 施行. X染色体の構造異常は認められなかったが, HRPT遺伝子の 1 アレルにpoint mutation（ヌクレ オチド40でGがAに変異) が見出された.

\section{結 論}

過去に報告例のないHPRT遺伝子変異の妊娠女 性例を経験したが倫理委員会の判断で妊娠を続 行することになった。 